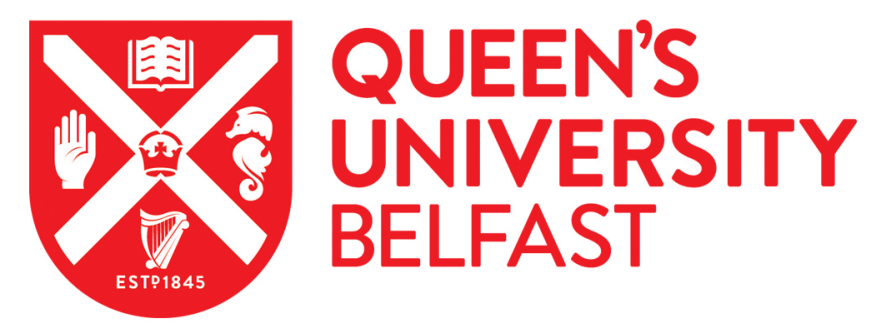

\title{
Pre-Retirement Age Migration to Remote Rural Areas
}

Stockdale, A., \& MacLeod, M. (2013). Pre-Retirement Age Migration to Remote Rural Areas. Journal of Rural Studies, 32, 80-92. https://doi.org/10.1016/j.jrurstud.2013.04.009

Published in:

Journal of Rural Studies

Document Version:

Peer reviewed version

Queen's University Belfast - Research Portal:

Link to publication record in Queen's University Belfast Research Portal

Publisher rights

(c) 2013 Elsevier Ltd. This manuscript version is made available under the CC-BY-NC-ND 4.0 license http://creativecommons.org/licenses/by$\mathrm{nc}-\mathrm{nd} / 4.0 /$ which permits distribution and reproduction for non-commercial purposes, provided the author and source are cited.

\section{General rights}

Copyright for the publications made accessible via the Queen's University Belfast Research Portal is retained by the author(s) and / or other copyright owners and it is a condition of accessing these publications that users recognise and abide by the legal requirements associated with these rights.

Take down policy

The Research Portal is Queen's institutional repository that provides access to Queen's research output. Every effort has been made to ensure that content in the Research Portal does not infringe any person's rights, or applicable UK laws. If you discover content in the Research Portal that you believe breaches copyright or violates any law, please contact openaccess@qub.ac.uk. 
accepted for publication: Journal of Rural Studies.

\title{
Pre-Retirement Age Migration to Remote Rural Areas
}

\section{Aileen STOCKDALE and Marsaili MacLEOD}

\begin{abstract}
Recent literature suggests that the increasingly blurred relationship between paid employment and retirement facilitates a retirement transition period, a life course stage, which may involve a change of residence. The role of such pre-retirement age mobility in the repopulation of rural areas has, however, received relatively little academic scrutiny. This paper draws upon findings from a two-year study conducted in three UK case study areas. It examines the extent of pre-retirement age (aged 50-64) migration into remote rural communities and the impacts this type of movement has upon economic activity, social and community engagement and service provision. It is argued that while this under-researched cohort offers opportunities to support the social and economic sustainability of rural communities (at least in the short and medium term), there are notable challenges which are likely to emerge as it ages in situ. The findings are particularly relevant given national trends on population ageing.
\end{abstract}

Key words: ageing, retirement transition, life course, in-migration, rural, economy and society

\section{Introduction}

The United Kingdom, in common with many other countries, is undergoing a process of population ageing. Within the next decade one in three of the UK's population is expected to be aged 50 or over, with one in four aged 65 and over by the 2040s (Cracknell, 2010). People are also living longer. The number aged 75 and over is set to double and the number aged 85 and over is set to triple by the middle of this century (Bernard and Phillips, 2000), with the number of centenarians expected to reach 100,000 (ONS, 2011). Population ageing, however, will not be felt uniformly either between or within individual countries (Davies and James, 2011). Within a UK context, Rutherford (2011) reports that West Somerset, South Shropshire and Berwick-upon-Tweed will have the highest proportions of people aged 65 and over by 2031, at over 45 per cent. Similarly, Rees (2003) predicts notable inter- and intra- 
regional differences resulting from the migration of particular age groups. Common destinations for retirement migration (such as Wales and South West England) will have the highest proportions of UK residents aged over 65 years. Moreover, because of continuing youth out-migration and the in-migration of older age cohorts it is widely expected that the consequences of population ageing will be felt first in rural areas (Champion and Shepherd, 2006; Stockdale, 2011). Indeed, a recent special edition of this journal has focused on 'Growing old in rural places' (Milbourne, 2012): however, few of its papers explicitly include a migration dimension.

Accompanying population ageing is an increasing recognition of the existence of a distinct mid-life life course stage which reflects increased diversity of, and fluidity between, what were previously orderly sequences of life events (such as, education, employment, family formation, empty-nesters, retirement). This is perhaps most notable at the traditional retirement stage of a person's life. Early retirement and flexible retirement options mean that the move into retirement is no longer the abrupt life course stage undertaken at the state pension eligibility age that it once was. According to Han and Moen (1999) there has been both a downward shift in the age of retirement and increasing variability in the timing of retirement. In addition, there is evidence of a retirement transition stage in the life course whereby the expectation of future retirement acts as a catalyst for behavioural changes, including a possible change of residence. This paper examines the migration of persons aged 50-64 (and, therefore, potentially at a retirement transition stage of their lives) to remote rural areas of the United Kingdom. During a period of national population ageing, the migration flows and the associated decisions of this cohort are likely to influence the geography of population in the UK for the foreseeable future and have long-term consequences for rural destination areas.

Understanding how these patterns of population change affect local rural areas requires an understanding of the interrelationships between population dynamics and local social and economic organisation. Rural areas in the UK are facing unprecedented change as a consequence of globalisation. Social and economic linkages, which are less constrained by distance, are underpinning the development of the 'New Rural Economy' (NRE) (Shucksmith et al., 2011). The NRE is characterised by a diversification of economic activity in response to changing consumption patterns. Unlike accessible rural areas, remote rural areas cannot 
capitalise on commuting and service provision to nearby urban and peri-urban areas; rather, a common response is the remodelling of 'the rural' as an important leisure destination for holiday makers, lifestyle migrants and retirement migrants alike. Attracting in-migrants to remote rural environments is linked both to new 'life-work' models and the capacity of a locality to provide services to support a high quality of life for those ageing in place (Philip et al., 2012). As such, in-migration flows are linked to broader processes of rural transformation which are producing an increasingly differentiated countryside (Shucksmith et al., 2012). Frequently in-migration is viewed as an economic and social asset for rural areas (Stockdale et al., 2000), although others demonstrate particular problems that arise as a result: housing affordability (Taylor, 2008), gentrification (Phillips, 2005; Smith, 2002; Stockdale, 2010), local service provision (Divoudi and Wishardt, 2004) and community cohesion (Murdoch et al., 2003). A key question we address here is, to what extent do pre-retirement age inmigrants (aged 50-64) and, therefore, those at a possible retirement transition stage of the life course represent an opportunity or a challenge to remote rural areas? The answer to this question is likely to be increasingly important to policy makers as the numbers reaching this and subsequent life course stages increase as a result of national population ageing.

The remainder of the paper is organised into six parts. First, we review the academic literature relating to the retirement transition concept and calls for mid-life to be recognised as a distinct stage in the life course for migration research, before turning to explore the potential economic and community consequences (identified from the literature) of rural (and mid-life) in-migration for destination areas. Second, our UK case study research is introduced and primary data collection approach described. Third, we examine the inmigration patterns reported in the case study areas and review pre-retirement age migrant origins and their decision-making influences. In section four, we focus specifically on the potential economic and community impacts of this cohort of migrants upon their destination communities, while in section five we report on the related challenges that rural areas are likely to face in the coming decades. Finally, in section six, we reflect on the usefulness of the retirement transition concept and the related distinctiveness of mid-life migration (relative to later and earlier life stage migration) in aiding our understanding of rural in-migration and its consequences for rural areas. We also bring together some longer term conclusions as they relate to an ageing society. Throughout, but especially in parts three and four, comparisons are made between study areas and with younger and older migrant cohorts (and non- 
migrants). This allows us to establish the opportunities and challenges resulting specifically from pre-retirement age in-migration relative to other life course stages and identify geographical variations. In doing so, the paper is intended to make a contribution to the literature on counterurbanisation, life course migration, and population ageing. We acknowledge the work of Halfacree $(2008 ; 2012)$ which draws attention to the spatial and temporal diversity of counterurbanisation flows. Our particular concern in this paper is with mid-life migrants to remote rural environments whose move is understood as potentially permanent.

\section{Retirement Transition, Rural In-migration and Potential Socio-Economic Impacts}

The relationships between migration and age (Millington, 2000), life course stage and events (Rossi, 1955; Michielin and Mulder, 2008; Bailey et al., 2004; Kley and Mulder, 2010), and previous residential experience (Fischer and Malmberg, 2001; Feijten et al., 2008) have long been acknowledged. Increasingly, however, migration research has been urged to adopt a life course perspective which acknowledges a continuum of life course changes, which do not correspond neatly with chronological age (Clark and Davies, 1990; Walters, 2002; Plane and Jurjevich, 2009 and Niedomysl, 2010). For example, Wulff et al. (2010) call for mid-life to be taken as a new life stage in migration research, while Geist and McManus (2008) explain that '... the family life-cycle perspective on adulthood as a staged progression through an orderly sequence of life events has given way to a life course perspective that emphasizes the variability of timing and sequencing of life events ...' (p.283).

Within this context, the concept of a retirement transition (Hayward et al., 1994) is relevant. It corresponds to a mid-life life course stage and acknowledges that the shift from employment to retirement is no longer the abrupt life event that it once was. Instead, from a life course perspective, the expectation of retirement acts as a catalyst for change, including a change in residential preferences as well as changing attitudes to work, health, lifestyle and marital relations (Carter et al., 1997; Lehr et al., 1998). The concept therefore refers to the behavioural changes affecting those at mid-life as they 'prepare' for the retirement stage of their lives; however, it has received relatively little academic attention in migration research with the exception of Bures (1997) and Stockdale (2006a). This is in contrast to migration studies which have identified retirement as a key life course stage (Rogers, 1992; Walters, 
2002). It would seem, therefore, that migration research to date has overlooked the possible role of pre-retirement, specifically retirement transition, migrants in rural in-migration flows.

Acknowledging possible geographical variations, rural in-migration (irrespective of the life course stage at which it occurs) is frequently viewed as an asset to rural areas. Stockdale (2006b), for example, alleges that such mobility can be a catalyst for rural economic regeneration. Research in rural Scotland reported 0.52 jobs were created per economically active migrant household (Stockdale et al., 2000) while, on average, every household headed by a self-employed migrant generated an extra 1.6 jobs in the rural economy (Findlay et al., 2000). Similar job creation potential has been observed by Bosworth (2008) in Northumberland and by Groves-Phillips (2013) in Wales, with Bosworth (2010) coining the term 'commercial counterurbanisers' to describe migrants who establish businesses. Inmigrants at the retirement transition stage of their life specifically are a potentially valuable asset for rural areas (Allen, 2004; Lowe and Baker, 2006). At this life course stage some seek paid employment in bridging jobs (including moving into self-employment) before completely exiting the labour force (Green, 2006; Marshall et al., 2001; Quinn and Kozy, 1996; Stallman et al., 1999; Yeandle, 2005). Those favouring self-employment, and any associated business start-ups, could represent something of an entrepreneurial infusion to rural areas. It is alleged, for example, that business start-ups by older groups are more likely to survive (Loretto and White, 2006) with Oughton et al. (2003) confirming that many rural small businesses have been started by middle-age in-migrants. Indeed Atterton (2006) calls '... on renewing the local population by deliberately drawing in sufficient numbers and types of pre-retirees, in addition to 'making the most of' those pre-retired who have already arrived' (p.35).

Research in Canada (Marshall et al., 2001) and the United States (Quinn and Kozy, 1996; Stallman et al., 1999) also suggests that rural areas may benefit from the in-migration of midlife and older households. US studies estimate that it takes 3.7 new manufacturing jobs to equal the economic impact of one new retiree household (Skelley, 2004) and that retiree inmigration creates 0.5 jobs per migrant (Serow, 2003). Such is the job creation potential that several countries have implemented programmes specifically seeking to encourage the inmigration of older persons to rural areas. In Japan Government departments encourage urban 
retirees to relocate to the northernmost island in the country; Hokkaido (Murakami et al., 2009) and some US states have introduced retiree-attraction programmes (Brown and Glasgow, 2008; Reeder, 1998). In Finland too, Jauhiainen (2009) acknowledges that if retiring baby-boomers can be encouraged to return to the rural periphery of Finland they can be a trigger for local economic development.

Others, however, take a more cautious stance. Most recently, Bosworth and Willett (2011) demonstrate that the likelihood of entrepreneurial in-migration is influenced by migrant motivations and perceptions of rurality, so that the economic impacts associated with rural inmigration are spatially variable. Green (2006) too argues that older people often use selfemployment as a means to supplement their income, while Herslund (2012) reports that many rural incomers find it difficult to fit their skills to the local labour market and, wishing to avoid a time-consuming commute, start businesses 'in order to get time to enjoy the 'rural idyll’' (p.248). Such motivations for becoming self-employed, while beneficial to the individual, are likely to have a limited impact on rural economic regeneration. This selfemployment is a personal or household activity, not an enterprise intended to develop into a business employing others. Moreover, Akgun et al. (2011) claim that there is little to distinguish local and newcomer entrepreneurs in terms of their contributions to rural development: instead it is differences in the preferred types of businesses established by each which may explain any differences in job creation.

The economic consequences of rural in-migration may be felt in other ways too. A decade ago the UK Government claimed that average pensioner's incomes are growing faster than average earnings (DSS, 2000). Lowe and Speakman (2006) claim that today's retirees are the most affluent this age group has ever been. The financial position of today's older age groups have been boosted by private and occupational pensions, individuals capitalising upon rising property prices and a larger proportion of the population investing in the stock market (ignoring for the moment the recent global financial and economic downturns). According to Baker and Speakman (2006) people over the age of 50 will account for the majority of expenditure in several sectors of the UK economy by 2043 while Findlay et al. (2001) note that retired in-migrants and older groups display a greater patronage for local rural shops and 
services. An inflow by affluent older persons may, however, contribute to rural gentrification processes (Phillips, 2005; Smith, 2002; Stockdale, 2010).

It is not just in economic terms that in-migration, and potentially retirement transition and older in-migrants, represent an opportunity for rural areas. These migrants may also make a significant contribution to the social fabric of rural areas. While numerous factors affect the likelihood of social participation by older age groups (Moen et al., 2000; Putman, 2000), previous research associates high rates of participation and volunteering with those aged over 50. For example, Foruijin et al. (2006 p. 363) state, '[T]hey are active in volunteering, as members of civic organisations, in giving assistance to others... and stay active in these activities during a long period in late adulthood'. Such participation is also acknowledged to be greater in rural than urban areas (Wenger, 2001; Fast and de Jong Gierveld, 2008) with older rural in-migrants believed to become quickly involved in community activities and organisations in the destination area (Brown and Glasgow, 2008; Erlinghagen and Hank, 2006; Le Mesurier, 2006; Warburton and McLaughlin, 2005). Recent Canadian research has also shown volunteer-based initiatives to fill gaps left by disappearing rural support services (Joseph and Skinner, 2012; Skinner and Joseph, 2011). Stockdale (2011) alleges that early retirement, self-employment and flexible employment all mean that middle-aged or postretirement migrant households to rural areas could represent a sizeable reservoir of potential community ‘volunteers', while Davis Smith and Gay (2005) highlight important links between in-migration, self-employment and volunteering.

Notably absent from the research studies reported in this section is a systematic investigation of retirement transition rural in-migration specifically and its possible opportunities and challenges for rural areas during a period of national population ageing. Based on the literature, rural in-migration, including that by older age groups, is frequently reported in positive terms for the rural economy and society. Accordingly, one would expect similar positive contributions to arise specifically from the in-migration of retirement transition stage migrants: although to date this particular cohort of in-migrants has neither been studied in its own right nor compared with migrants at other stages of the life course. This paper seeks to address this gap in the rural migration literature. 


\section{Methodology and Data}

This paper analyses data from three remote rural case study areas of the UK: the Glens of Antrim (Northern Ireland), Radnorshire (Mid-Wales), and the Isle of Bute (Scotland) (Figure 1). All three were selected on the basis of an analysis of the 2001 Census of Population, and specifically the Sample of Anonymised Records and Special Migration Statistics, which showed that these areas had recorded an in-migration rate by those aged 45 - 59 years above their (respective) national rural average ${ }^{1}$. In the remainder of the paper we define the preretirement age cohort as aged 50-64 (that is, the cohort immediately below the (current) UK state pension eligibility age of 65 and therefore potentially at a retirement transition stage of their life course). In their national contexts the three study areas have in common an older population, a long standing trend of youth out-migration, fragile economic structures and low wage economies, outstanding scenic environments and proximity to small towns. They are, however, not homogeneous. For example, the Glens of Antrim population has the lowest mean age: Northern Ireland's population is the 'youngest' of the four nations in the UK. Bute has the oldest population profile, with a a third of the 2001 population being over the age of 60, compared to only 20 percent in the Glens of Antrim. Radnorshire has experienced notable population growth in recent decades whereas the populations of the other two areas have declined.

A mixed method data collection approach was adopted. First, a 'drop off and collect' household survey was conducted in each area using a random list of target addresses generated from the most recent edited electoral register. This was supplemented by a postal survey targeting specifically pre-retirement age (aged 50-64 years) migrants. This purposive sample was comprised of persons living in the study areas who had first registered with a local GP (since 2000) when aged 50 or above. This postal survey was administered on our behalf by national agencies responsible for patient registration data. In total 650 questionnaires were completed, with a response rate of 64 percent and 22 percent obtained respectively for the 'drop off and collect' and postal surveys. Second, 33 semi-structured interviews were undertaken with households characterised by migrant type (these households

\footnotetext{
${ }^{1}$ The study areas were based on local authority electoral wards that, in the case of Scotland and Wales, had inmigration rates for the 45-59 age cohort that were +2 standard deviations above the mean. In Northern Ireland the study area's in-migration rate was +1 standard deviation above the mean. The Census data age category $45-$ 59 corresponded most closely to a retirement transition phase in the life course.
}

8 | $\mathrm{P}$ a g e 
are defined in the following section). These interviews adopted a life history approach by chronologically identifying moves related to specific life events (such as, childhood, employment, marriage, family formation, empty-nest, retirement, and bereavement). Others have advanced such an approach to incorporate life trajectory diagrams (Davis, 2011; Davis and Baulch, 2011). Our interviews sought to more fully understand the households' migration histories at different stages of the life course and the households' economic and social contributions to the local area following the move into the study area. Where extracts from these interviews are presented a pseudonym is used. Third, semi-structured interviews were conducted with 12 national and local public and voluntary service-providers across the three study areas, in order to ascertain perceptions of rural in-migration, and retirement transition in-migration in particular.

\section{Figure 1: Location of study areas}

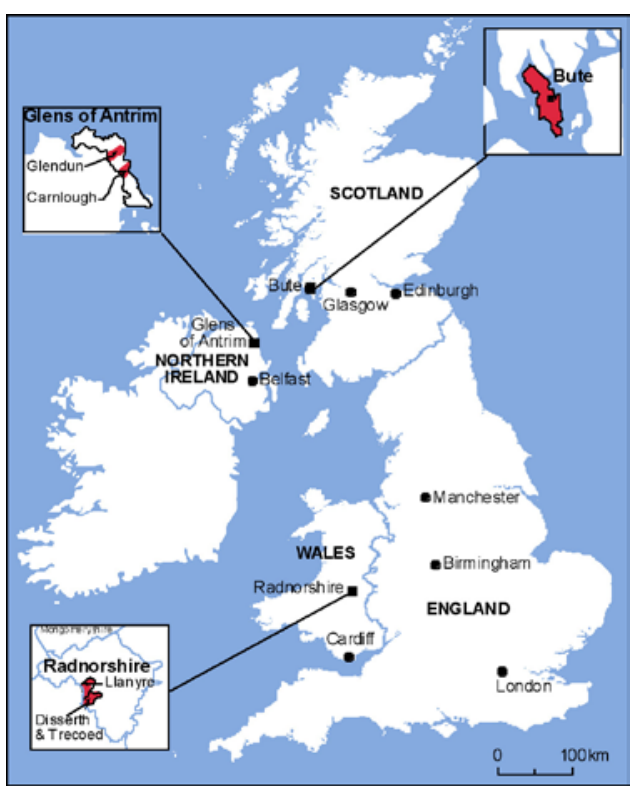

\section{Pre-Retirement Age In-Migration and Associated Decision-Making}

The household survey invited respondents to provide information about their household's residential history. Responding households were classified in three ways: First, as having made no-move (households that had lived at the same address since the current household was formed) or were mover households. The survey captured 464 mover households (Table 1) and 67 percent had moved since the year 2000. Second, mover households were then differentiated on the basis of the head of household's age at the time of their move to the 
current address: under 50 years; aged 50-64; or aged 65 and over. The head of household was as identified by the survey respondent and in two out of every three households was male. Our analyses use data for the (respondent-defined) heads of household to categorise household characteristics. We acknowledge that this is a potential criticism for some readers. These three age categories allowed us to distinguish pre-retirement age (and potentially retirement transition life course stage) migrants from younger and retirement life course stage migrants. At least half of the mover sample moved to their current address when the head of household was aged under 50 and a further 30 percent moved at pre-retirement age (50-64 years). Pre-retirement age mobility, therefore, represents a not insignificant share of all mover households. Third, the mover households were further categorised in terms of the distance moved: a local move (households which had moved a distance of less than $15 \mathrm{kms}$ to their current address) and a non-local move (households which had moved 15kms or more to their current place of residence). In Bute, this distinguished between moves 'within' and 'onto' the island. In the remainder of this paper we define migrant households as those which have undertaken a 'non-local' move into the study areas (numbering 247 and representing just over half of the total mover households captured by the survey), and nonmigrants as those having undertaken either a 'local move' or 'no move'.

Mobility differences were observed between the three study areas. The Glens of Antrim is associated with a low level of household mobility with 40 percent of respondent households identified as 'non-movers'. This compares with just four and six percent in Bute and Radnorshire respectively. A 'non-local move' (that is, migrant households) is most frequent in Radnorshire. Here approximately two-thirds of all mover households relocated over a distance of $15 \mathrm{kms}$ or more (compared to 45 and 24 percent respectively in Bute and the Glens of Antrim). Of these migrant households to Radnorshire three-quarters moved in excess of $80 \mathrm{kms}$.

Table 1: Mobility Flows - Head of households' age at time of move (all study areas)

\begin{tabular}{|l|c|c|c|c|}
\hline & Under 50 & $\mathbf{5 0 - 6 4}$ & 65 and over & Total \\
\hline $\begin{array}{l}\text { Local move (within } \\
\text { 15kms) }\end{array}$ & $154(63 \%)$ & $40(28 \%)$ & $23(30 \%)$ & $217(47 \%)$ \\
\hline $\begin{array}{l}\text { Non-local move (15kms or } \\
\text { more) }\end{array}$ & $92(37 \%)$ & $101(72 \%)$ & $54(70 \%)$ & $247(53 \%)$ \\
\hline Total & 246 & 141 & 77 & 464 \\
\hline
\end{tabular}

Chi-Square $=52.9$ (statistically significant at 99\% level with 2 degrees of freedom).

$\mathbf{1 0} \mid \mathrm{P}$ a g e 
The migration patterns associated with different stages of the life course are compared in Table 1 with statistically significant differences observed. Households that moved when the head of household was of pre- (aged 50-64 years) or post-retirement (65 years and over) age were most likely to have undertaken a 'non-local' move into our rural study areas when compared with the younger (under 50) age cohort and therefore earlier life course stages. This pattern is repeated in each of the three study areas with the exception of Bute in relation to the 65 and over cohort. In Bute, those of post-retirement age had generally participated in a local 'within-island' move. We will return to this variation later in the paper when discussing some of the challenges associated with mid-life in-migration to rural areas. The overall pattern supports the findings of Bures (1997) and Stockdale (2006a) that pre- and postretirement age migrants undertake similar migration flows. In addition, it highlights the importance of pre- and post- retirement age migrants to rural in-migration flows: 41 percent (101 households) moved into our study areas when the head was aged 50-64 (pre-retirement age) and a further 22 percent did so when the head was aged 65 or over. Specifically, preretirement age (and potentially retirement transition life course stage) in-migration accounted for 44 percent, 42 percent and 31 percent of the total migrants to Radnorshire, Bute and the Glens of Antrim respectively.

Focusing specifically on the origins of migrant households, 59 percent originated from an urban area. However, this disguises notable geographical and life course stage variations. For example, urban-origin flows range from 53 percent for Radnorshire to 74 percent for the Glens of Antrim, and from 52 percent of moves undertaken by those aged 65 and over to 66 percent of moves undertaken by the pre-retirement (50-64) age cohort. Migration into our study areas is, therefore, characterised by a strong counterurban flow (with the possible exception of those moving to Radnorshire, and those moving at post-retirement age). Among those moving at the pre-retirement age (or retirement transition life course stage), one in four moved from a city (with a population of at least 75,000), 42 percent from a large town, and one in five from another rural area. The latter was most evident among pre-retirement age migrants to Radnorshire (30 percent). In addition, Radnorshire displayed high levels of inmigration from England (accounting for 79 percent of those aged 50-64) and from the Midlands, London and South East regions in particular. In-migration from England also 
accounted for one third of pre-retirement age migrants to Bute (with northern England, London and the South East the most popular regions of origin). Moves from elsewhere in Scotland, however, dominate for Bute (especially from Glasgow, East Dunbarton, and Lanarkshire).

In accordance with the literature (Bures, 2009), migrants moving at this stage of their lives (when aged 50-64) generally comprised of couples with no children living at home (empty nesters). The majority enjoyed good health at the time of the survey (less than six percent of either the heads of household or their spouse/ partner described themselves as long-term sick or disabled). These households were also associated with high levels of early retirement: 37 percent of household heads had already retired prior to the move and a further 23 percent retired at the time of the actual move. Despite being below the state pension eligibility age of 65 years, 60 percent of migrant heads of households were, therefore, retired immediately following the move into our remote rural study areas. This figure is likely to be an underestimate of the true number of migrant households containing at least one early retiree: the household survey did not collect data on the economic status of the heads' spouse/ partner before and after the move. Therefore, the analysis does not take into account that the economic status of spouses/partners may also have changed as a result of the move. What is clear from the analysis of heads of household data is that migration into these areas is linked to a retirement life course stage rather than to the emergence of a distinctive retirement transition stage and that this retirement life course stage itself is becoming increasingly blurred in relation to chronological age. This is further substantiated by pension data derived from the survey: 38 percent of pre-retirement age migrant heads of household were in receipt of a pension prior to the age of 60 . When compared to other migrant age-groups, preretirement age householders had a less mobile work history: 44 percent had spent the majority of their working life with just one employer. It is perhaps because they had been employed for most of their working life with one employer that they were both able to retire prior to the state pension eligibility age and had adequate financial plans in place for early retirement. Such an interpretation is supportive of Han and Moen's (1999) acknowledged link between retirement and the individual's career pathway. Our finding corresponds to the 'orderly' career pathway (continuous employment in a single organisation) which Han and Moen associated with early retirement. 
In common with other migration studies which have associated rural in-migration processes generally with particular socio-economic groups, and middle-class persons especially (Phillips, 1998; Stockdale, 2010), occupational data tentatively suggests that this is also likely to be the case for the 50-64 age cohort of migrants in this study. Unfortunately the household survey did not capture the previous occupation of retired migrants and only 20 heads of migrant households, who moved into the study areas when aged 50-64, remained economically active at the time of the survey. Equally, for 82 of the 91 households comprised of a couple both the head of household and their spouse/ partner were retired at the time of the survey. Of the 20 heads of household who remained economically active, twothirds were either managers and senior officials or in professional occupations (using the SOC 2000 classification of occupations). This though does not necessarily mean that preretirement age migrants are an especially affluent group, as measured in terms of annual incomes (at the time of the survey). To the contrary, in this study while the modal household income band for non-migrant households is $£ 20-£ 30,000$ per annum (26 percent), among all migrant households (31 percent) and pre-retirement age migrant households specifically (38 percent) the modal income per annum is $£ 10-£ 20,000$. This is likely to reflect the higher number of retiree (measured in terms of the heads of households' economic status only) migrant households (59 percent) relative to the non-migrant household sample (34 percent). When considering household affluence, one should also bear in mind that a greater proportion (80 percent) of pre-retirement age migrant households owned their homes outright compared with all migrants (62 percent) and non-migrants (42 percent). Therefore, while the modal annual income among pre-retirement age migrants may be lower they, free from mortgage payments, are likely to have greater disposable incomes.

Turning now to the motivations for moving to our rural study areas at pre-retirement age further evidence is obtained to support the fact that such migration is commonly part of the retirement event itself and less frequently part of a sequence of events which leads to eventual retirement. 30 percent of pre-retirement age migrant households were motivated to move to their current address by actual retirement. This was most frequently expressed among those moving to the Glens of Antrim (47 percent) and least frequent among migrants to Radnorshire (23 percent). A further 27 percent were motivated by quality of life reasons 
(and was most frequently stated among those moving to Bute). Quality of life motivations are undoubtedly connected to representations of rurality (Benson and O’Reilly, 2009) and are often only acted upon following an exit from the labour market. This aspect is elaborated upon in the following paragraphs. The motivational data analysed, in contrast to the economic status data presented above, does provide tentative evidence of the existence, or emergence, of a retirement transition life course stage and its association with rural inmigration by those aged 50-64 years. A small group (16 percent) of these households gave planning for retirement as the main motivation for moving to their current address. This was most evident in Radnorshire. Planning for retirement corresponds to our conceptualisation of a retirement transition life course stage, that is, the move is in preparation for the retirement life course stage. Further analyses of these 'planning for retirement' migrants suggest that, notwithstanding the small numbers, such migrants were more likely to have been selfemployed immediately prior to their move (44 percent). For comparative purposes, younger migrants (aged under 50 years when moved) were motivated by a greater variety of reasons including personal (29 percent), housing (27 percent), quality of life (20 percent) and employment (19 percent). Actual retirement (38 percent), personal and familial (28 percent), quality of life (11 percent) and housing (11 percent) reasons dominated the decision-making of post-retirement age migrant households. Once again, the importance of actual retirement as a motivation among those who had reached retirement age is further evidence that migration is part of the retirement event itself.

In Radnorshire approximately half of pre-retirement aged migrants had no prior connection to the area. By comparison, the vast majority of those moving to Bute and the Glens of Antrim had, including previous residence, holidays or second-home ownership. Specific to the Glens of Antrim, second generation return migration has been observed (Stockdale et al., 2012). Further insights on the motivations for migration emerged from the interview data. A recurring theme was that this 'mid-life' stage of the life course was an enabling period for a move to a rural area. The following selection of interview excerpts illustrates typical motivational scenarios associated with pre-retirement age rural in-migration. These are intended to give a flavour of the associated decision-making processes. A fuller analysis of this qualitative data is the subject of a separate paper. 
There were those who at mid-life not only had taken early retirement but any children had also left home. For some couples this led them to re-evaluate their financial position and especially their finances in relation to property.

'The children had effectively flown the nest. ... We found ourselves in a position [like others] who take early retirement, in that money was tied up in the house. I said 'look, I think we could put ourselves in a much better [financial] position, perhaps see another part of the country ... - let's downsize.' [A couple moving to Radnorshire from England]

For others, freed from the locational constraints of their workplace, the shift into retirement enabled couples to realise a long-held residential preference for a less hectic pace of life (relative to urban areas) and/or a more natural environment. Such quality of life aspects of the move were frequently expressed:

'To be able to walk out of the front door and walk down a country lane, beside a river and see dippers in the river and the birds flying around.... We've seen red squirrels in the garden.... You can see the stars over here ... You can see the weather! We see the clouds coming down here [through the glen]....' [A couple moving from SE England to the Glens of Antrim]

On other occasions quality of life motives represented only one of multiple considerations leading to the move. For example, a couple who cited value for money in terms of housing affordability as the main reason for relocating to Wales went on to highlight why, at the time they moved, they did not consider returning to a house they also owned in an English city:

'...It was definitely a conscious decision to get out of the rat race. I think we'd both had enough ... When I go back now it's an absolute nightmare: too many people, too many cars, the pace is wrong. I just hate it. I feel like I'm coming over with some sort of allergy!'

Others had long-held plans to relocate to the area but were only able to enact these plans upon retirement, for example, they had purchased a holiday home in the area some time earlier and had been frequent visitors during the latter years of their working life.

'[W]e had ten days [holiday] on Bute .... we liked it so much in that ten days, we bought a place [as a holiday home]. .... And so eventually we decided that we would retire here.' [A couple who moved from SE England to the Isle of Bute]

Other prior associations were also commonly reported. For example, family connections and childhood visits were often influential:

'.... My mother is [from] Cushendun [a small settlement]..... See, [when I was a child] we came here during the holidays ..... we'd be here for seven or eight weeks [during the summer].'[A couple who both had been brought up in England and lived/ worked there all their adult lives. The husband's mother was a native of the Glens of Antrim and the couple moved there following early retirement]

These motivational excerpts reveal how retirement enables people to seek places which are congruent with their sense of selves, and in particular, with their sense of their retired self. 


\section{The Impacts of Pre-retirement Age In-migration to Remote Rural Areas}

In this section, attention turns to the possible impacts of pre-retirement age in-migration for rural areas. Impacts are assessed in terms of entrepreneurial activity and job creation, rural expenditure, and involvement in local groups and activities. Throughout we draw comparisons with the in-migration of other age cohorts and with non-migrant households (where differences are noted). Specifically we ask, to what extent does pre-retirement age inmigration (and therefore those at a possible retirement transition stage of their life course) represent an opportunity for rural communities?

\section{Economic impacts and job creation}

Notwithstanding the high share of pre-retirement age heads of migrant households who were retired (60 percent), immediately following the move, 13 (13 percent) were self-employed. Pre-retirement age in-migration does, therefore, bring some potential for entrepreneurial activity into rural areas as measured by self-employment rates, but it is significantly less than that arising from the in-migration of younger households (whereby 26 percent of heads were self-employed). No notable differences were observed between the three study areas. Of the 13 heads that were self-employed, 11 of these were already self-employed prior to moving. A move to our study areas was not, therefore, associated with a change in the mode of employment. Once again this would appear to deny the existence of a retirement transition in relation to the working patterns of migrant heads of households. For example, the literature suggests that a shift from employee status into self-employment may characterise a retirement transition life course stage. Instead, our data suggests that the move to a rural area may only be part of a retirement 'planning' and therefore transition stage for those already selfemployed. It is worth emphasising that a change of residence and a shift into selfemployment and/ or the establishment of a business will not necessarily occur simultaneously. Among our respondents only two pre-retirement age heads of households had made a shift from full-time employment (immediately following the move) to selfemployment (at the time of the survey). Those who perhaps established a business some time after moving and were no longer in business, for whatever reason, at the time of the survey were not captured through our household questionnaire. Therefore, the 13 reported here is likely to be an under-estimation of the true number self-employed or running a business among the pre-retirement age cohort of migrants. Equally, it should be noted that five of 
these heads had retired by the time the survey was conducted: thus, any benefits to the rural economy from pre-retirement age business ownership are unlikely to be long-term.

Nine of the 13 who were self-employed immediately following their move gave planning for retirement and quality of life motivations as principal explanations for the move. The quality of life motivations are consistent with Herslund (2012) and Bosworth and Willett's (2011) view that some rural business-owning in-migrants are 'influenced by an anticipated holiday lifestyle and the consumption of space' (Bosworth and Willett, 2011:210). Moreover, Bosworth and Willett (2011) make an important link between business start-ups and migrant motivations suggesting that those 'seeking an escape from modernity are unlikely to be catalysts for the turnaround of [Cornwall’s] economic fortunes' (p.210).

Across the three study areas, 144 businesses (Table 2) were currently owned or part-owned by respondents to the survey, of which 35 percent (numbering 51) were owned by migrant households (irrespective of the migrant's age at the time of their move). Of these, approximately one-third respectively had been established prior to the move, in the same year as the move, and following the move (with an average of three and half years having elapsed between the move and the business start up). Proportionately, 18 percent of migrant households owned a business as compared to 27 percent of non-migrant households in our sample $^{2}$. No differences were noted between the origins of the household: 57 percent of migrant business owners had moved from an urban environment compared to 59 percent of non-business owning migrant households. Of the 51 migrant-owned businesses only 12 were owned by pre-retirement age migrants. The majority instead were owned by a younger age cohort of migrants (aged under 50 years at the time of the move).

Because of the small number of migrant owned businesses captured by the survey it is not meaningful to disaggregate this data by study area or by migrant age at the time of the move. Collectively, however, a number of business characteristics can be identified (Table 2). The most common types of businesses owned by migrant households were farm-related, consultancy type professional services (for example, in financial services or architecture), bed

\footnotetext{
${ }^{2}$ It is acknowledged that as migrants are older, many at the time of the survey were of post-retirement age, and as such were less likely to own/part own a business than non-migrant households.
} 
and breakfast and other tourism-related activities, internet sales, and arts and crafts. By comparison, non-migrant owned businesses were more narrowly concentrated in the agriculture, fishing or forestry and building and construction sectors. The majority of businesses were run from home. If membership of a local business organisation is taken as an indicator of the importance of, or the owner's entrepreneurial commitment to, the business the results are far from encouraging. In the absence of such 'local business networking' it would appear that many rural businesses are individual ventures as opposed to contributing to a wider business community. This is further borne out when we consider the employment opportunities created within these businesses.

Table 2: Business characteristics by owners' migrant status

\begin{tabular}{|l|l|l|}
\hline & Migrant-owned & Non-Migrant-owned \\
\hline Sector (most frequent) & & \\
\hline Agriculture, fishing or forestry sector & $25 \%$ & $47 \%$ \\
Accommodation and food services & $16 \%$ & $24 \%$ \\
Arts and crafts & $14 \%$ & $9 \%$ \\
Professional services & $9 \%$ & $6 \%$ \\
\hline Employees & & \\
\hline Number employed in business (including owner) & 106 & 352 \\
Average number of employees per business & 2.1 & 3.78 \\
\hline Other Characteristics & & \\
\hline Run from home & $61 \%$ & $64 \%$ \\
Members of a local business organisation & $13 \%$ & $16 \%$ \\
\hline Total Number of Businesses (N) & $\mathbf{5 1}$ & $\mathbf{9 3}$ \\
\hline
\end{tabular}

Businesses owned or part-owned by migrant households employed on average 2.1 jobs per business, including the business owner themselves (Table 2). This is considerably less than for non-migrant owned businesses and reflects the greater opportunities for job creation among the business types (agricultural and building sectors) favoured by non-migrants (Akgun et al., 2011). The employee levels associated with migrant owned businesses are comparable to those cited by Findlay et al. (2000) and Bosworth (2008), however, the majority (78 percent) of these jobs are linked to businesses whose owner moved when aged under 50. Only 19 jobs were created by pre-retirement age migrant business owners. 
Rather than creating jobs for others, businesses owned by pre-retirement age migrants (at the time of their move) were more likely to operate as essentially one person/self-employee ventures as explained in the interview quote below:

'In the first number of years that I came here I operated just a small human research consultancy business but that was just me. And I can think of two other people that have come to live here that are working on their own from home. But not employing anyone ... It would be that people moving in are working as self-employed; it's them themselves. It's not bringing employment.' (Glens of Antrim)

In addition, only 60 percent of the jobs created were full-time positions, and of these threequarters were filled by family members. The following quote is from a pre-retirement age (return) migrant who purchased a small food service business in the Glens of Antrim:

'So we've got our cousin- the chef and one of the commi chefs is another cousin. One of the barmen is our cousin who lives up the road there.'

The limited job creating potential offered by migrants, especially pre-retirement age migrants, was recognised by Powys Regeneration Partnership:

'... It's casual and it's seasonal work. Or I think a number of wives have gone home to work rather than maybe working for the local authority or whatever. [Names business] that lady doesn't want to employ anybody. But she isn't making products because she's just tutoring. ... It's like artists - they are artists so unless they want someone to come in and be a marketer for them, which is pretty much not on their agenda. [They don't employ others] because you can't just come in and say 'paint like that', it's your own style.'

Moreover a representative from Bute Local Community Development acknowledged the links between the types of businesses being established by migrants, the individual's quality of life motivations, and their stage in the life course:

'[T]here are some who come in, set up small businesses, they've done their thirty-five to ninety-five hours a week [elsewhere] and they want something they can gain control of. We've got a lot by way of IT businesses, small IT businesses run from the house. One person but they control the amount they want to do. And I think there will be a lot of that .... There's a very high number of arts people on Bute .... Those kind of things they can control - their actual hours - and have a life.'

Similarly, the interview with Powys Regeneration Partnership emphasised that the establishment of a micro business commonly facilitates the migrant household's preferred work-life balance, as opposed to any entrepreneurial ambitions:

'.. we've had quite a lot of people coming in and buy thirty, forty acres small holdings, equine and that's - it's not employing people, it's more of a lifestyle.'

Such comments fit neatly with the concept of a retirement transition stage to one's life, including changing attitudes to work and lifestyle. However, we found limited evidence of such 'retirement transition' migrants in our study. Instead, early retirement dominated. Of the 19|P a g e 
small number that did run a business few were associated with job creation. On a more positive note for the rural economy the very fact that these individuals employ themselves (and on occasions other family members) mean that they are not 'taking jobs away from local people'. Furthermore they bring another household with purchasing power that can potentially be spent locally.

Migrant households can make other potential economic contributions to the rural destination area through employing domestic services and enhanced spending in the local area. Our survey recorded that 59 (23 percent) migrant households pay for gardening and/or cleaning services on a regular basis: a similar proportion was calculated for non-migrant households. However, it was age at the time of the move, not migrant status, which was a significant determinant: 41 percent of post retirement age migrants (at the time of the move) pay for these low skilled and low paid domestic services compared to just 13 percent among the under 50 cohort. Arguably the increased use of such services by older cohorts is unlikely to have much of an economic impact on the rural economy overall, but the additional income to the households where an individual is employed in this part of the service sector could be what makes it possible for them to remain living in a remote rural area with limited job opportunities. Similarly, many migrant households (irrespective of age at the time of their move) stated a desire to use local skilled tradesmen when the need arose:

'I don't employ anyone directly myself. ... I do support local businesses. Wherever possible I use a local tradesman. I've renovated my house; I've had work done to the garden. All was done my local tradesmen.' (Early retiree to Radnorshire from SW England).

Again, the value of these customers to local trades should not be under-estimated, even though it is difficult to quantify without undertaking local business surveys.

In addition, might migrants, and pre-retirement age migrants in particular, be more likely to purchase goods and services within their local area? We found that, as a group, migrant households are no more or less likely to use local services or shops than non-migrant households. Similarly, there are no differences between the different age cohorts of migrants. With the exception of low cost items such as milk (which three-quarters of all households in the sample purchase in the local area) the data signals considerable leakage out of the rural economy irrespective of migrant status, age at the time of the move or study area. For example, less than half of the households surveyed did their main grocery shop, purchased 
petrol or diesel, or obtained postal services within the local area. However, the availability of such services is often limited in these remote rural locations. For example, there is no local petrol station available to residents in the northern villages of Cushendun and Cushendall (within the Glens of Antrim). This indirectly has a knock-on effect on the use of other services in these villages as explained below (or alternatively it is because of the large supermarkets in neighbouring towns that local rural providers are unable to compete and hence go out of business):

'One of the problems is the lack of fuel. Petrol - there isn't a petrol station here now. The nearest is Carnlough or Ballycastle. There used to be one in Cushendall but he closed down. There is no other petrol station. So the way we do it, when we go to Tesco's [in Ballymena an important service centre] we fill up and do our grocery shopping at the same time.' (Glens of Antrim)

In Radnorshire too until the opening of a Tesco supermarket in the main service centre of Llandrindod Wells (in 2010) many residents shopped in other towns including Newtown and Hereford (across the English border).Village services are also being reduced, for example, a post office in a local village closed during the period between the survey and interview phases of this research. Residents in the area now rely on the post office in nearby Llandrindod Wells. Other shopping opportunities remain poor in Llandrindod Wells as explained by a retired non-migrant:

'[For grocery shopping we] nearly always go to Llandrindod. And they've just opened a new Tesco there, wonderful it is! ... [Hereford] is the place most people go if they want to buy anything. Llandrindod is very poor for clothes. It's OK for groceries and things but there's not a lot of choice. Most people will go to Hereford or Newtown to do any other shopping.'

Overall then, pre-retirement age in-migration seems to bring limited explicit economic benefits to rural areas. Businesses owned or part-owned by migrants appear to be individual household ventures which facilitate a change in lifestyle (most had been business owners/ self-employed prior to moving) and provide economic activity for the migrant or his/her family. Job creation is greatest in non-migrant owned businesses and, within the migrant business group, younger age groups at the time of moving (as opposed to pre-retirement age migrants specifically). It would seem therefore that the quality of life and life course stage decisions associated with pre-retirement age migrants are not leading to the establishment of business types offering job creation opportunities and as such are unlikely to bring about a significant economic regeneration of these rural areas. Local expenditure is also limited; however, this is explained by the low availability of shopping opportunities within our study areas rather than any desire by migrants to shop outside the local area. The following section 
explores how pre-retirement age migrants might make a positive contribution to their host community in other ways.

Wider benefits of in-migration

The academic literature suggests that older in-migrants in particular contribute to the development of social capital through participation in community activities and volunteering in local groups and charities (Fortuijn et al., 2006; Brown and Glasgow, 2008). Our household survey found that many households (both migrant and non-migrant) were frequent participants in a variety of activities (Table 3): church or religious activities, social or fundraising, and special interest groups (such as, local history, cultural, or horticultural groups) were most popular.

Table 3: Proportion of households claiming to frequently participate in local groups

\begin{tabular}{|l|l|l|}
\hline & Migrant Households & Non-Migrant Households \\
\hline Social or fundraising & $26 \%$ & $23 \%$ \\
\hline Sports \& fitness & $18 \%$ & $21 \%$ \\
\hline Church or religious & $29 \%$ & $37 \%$ \\
\hline $\begin{array}{l}\text { Community or Parish } \\
\text { Council }\end{array}$ & $6 \%$ & $5 \%$ \\
\hline Special Interest & $24 \%$ & $13 \%$ \\
\hline $\begin{array}{l}\text { Club/ activity for elderly } \\
\text { persons }\end{array}$ & $8 \%$ & $4 \%$ \\
\hline Total households & 247 & 403 \\
\hline
\end{tabular}

However, frequent participation for several local activities was highest among households headed by a pre-retirement age (at the time of the move) migrant. For example, one in every three was involved in social or fundraising activities and special interest groups. Moreover, migrant heads of households (or their spouse or partner) are more likely to volunteer for a local community service or activity (25 percent vis-à-vis 16 percent for non-migrant households), and amongst migrant households such volunteering is greatest among those headed by a pre-retirement age person at the time of their move. This was particularly pronounced in the Glens of Antrim (57 percent) and the Isle of Bute (38 percent). This higher level of community participation may simply reflect the fact that older - often retired residents are more likely to have the time to volunteer. Non- migrants in the same age groups are more likely to have family living in the area and if they, for example, provide informal care for grandchildren they do not have time to devote to voluntary activities. 
It is worth also noting that among the migrant sub-sample no differences were observed between volunteering and the origin of the household: 25 percent of migrant households moving from an urban area (and 27 percent from a rural area) possessed at least one volunteer in a local community service or activity. By comparison, motivational differences were observed. Migrant households motivated to move to our study areas for impending or actual retirement reasons were most likely to contain at least one volunteer in a local community activity (38 percent) at the time of the survey. This compares to 21 percent giving quality of life reasons and 19 percent giving a variety of other reasons to explain their move.

Retirement-motivated migrants are likely to have the time to devote to voluntary work, with three-quarters of those planning for retirement at the time of the move having actually retired by the time of the survey.

Not only were household members volunteering, but one quarter (24 percent) of all households in our sample contained at least one adult who held a position of responsibility in a local group, such as, chair, secretary or committee member. On Bute and in Radnorshire there was very little difference between migrant and non- migrant households: but migrants into the Glens were almost twice as likely to hold a position of responsibility as nonmigrants. Once again within the migrant sample across all three areas, it is households headed by someone of pre-retirement age (at the time of the move) that are most likely to take on such responsibilities: 36 percent of all migrant households contained at least one household member in a position of responsibility (and of those holding such positions, 53 percent came from households headed by a pre-retirement age migrant).

Representatives from the voluntary sector commented on the importance of older persons (but not explicitly older migrants) to community and civic life at interview:

'[T] he majority [of volunteers] are older people themselves. I would say fairly newly retired people that have wanted to use either what they've used in their professional life and want to carry that on or want to do something different. I would say that most are in that fifty to seventy-ish bracket.' (Radnorshire)

'If I'm answering your question honestly, it probably is a predominance of older, maybe nearly retired people or people who have retired early. From fifty up [who volunteer for us].' (Glens of Antrim)

It would seem, therefore, that pre-retirement age and older migrants to rural areas, and especially those motivated by impending or actual retirement, represent a particularly valuable community asset. According to Halfacree and Rivera (2012: 104) '[t]his may be 23 | P a g e 
interpreted as the migrants' attempt to (re)create a communitarian spirit and shape local social life to their images, as well as an effort to integrate in the community by taking an active role in social life.'

\section{Challenges arising from pre-retirement age migration to remote rural areas}

Up until now we have concentrated on the potential economic and social/ community opportunities associated with migration and pre-retirement age migration specifically, to remote rural areas. It would be remiss not to also consider some of the related challenges such migration will bring. Our arguments centre on two important facets: first, the challenge to make greater use of the considerable potential offered by pre-retirement age in-migration for the benefit of destination areas, and second, the significant challenges that are likely to emerge in these areas as this cohort potentially ages in place.

While it was thought pre-retirement age migrants may participate in a retirement transition phase of their lives, including a shift into 'bridging jobs' before completely exiting the labour market, those in this study were more likely to have undertaken 'early retirement' and an early exit from the labour market which has resulted in limited entrepreneurial activity and job creation (relative to the younger age migrant cohort and non-migrants). This would seem to contradict Stockdale (2006b) and support Bosworth and Willett's (2011) view that inmigration generally may not necessarily reverse the economic fortunes of rural areas. Preretirement age in-migration makes a small, yet not insignificant, entrepreneurial contribution but a particular challenge to policy-makers and those charged with regenerating remote rural economies is how to encourage greater numbers to move beyond essentially one-person selfemployed entrepreneurial activity and embrace business expansion and the types of businesses capable of employing others. In other words, a challenge is to 'attract' more entrepreneurial migrants to rural areas (irrespective of their stage in the life course). There is no doubting that migrants, including the pre-retirement age cohort of migrants, possess entrepreneurial skills and ability (18 percent of both all migrant heads and pre-retirement migrant heads specifically had been self-employed prior to moving), however, more often than not these skills (if utilised following the move) are used for the benefit of the migrant household rather than making a wider contribution to remote rural economic regeneration. One could argue, in common with Akgun et al. (2011), that rural in-migrants favour business $24 \mid \mathrm{P}$ a g e 
types which are unlikely to offer substantial job creation potential. The associated bed and breakfast, arts and crafts, and consultancy-type businesses established by pre-retirement age migrants especially are consistent with a personal desire to strike a lifestyle change and a greater work-life balance at this stage of the life course. This is supportive of Herslund (2012). But might policy initiatives be developed and implemented to encourage modest business expansion to the point where at least some employment opportunities may be created? Equally worthy of consideration, irrespective of the actual job creation potential associated with individual migrant businesses, might greater use be made of the migrants’ business acumen? For example, migrant (and indeed all) business owners could represent a considerable source of business advice and guidance to those in the local area contemplating a business venture. Such a business mentoring role could complement current services provided by economic development agencies. A Regeneration Partnership saw the potential in this idea. At interview, they commented:

'There is opportunities there for those people who have probably been in business, done very nicely and been successful marketers, salespeople or whatever so these basic skills which the small businesses need ...they give it back because they want to, ... they probably don't want a consultancy fee type thing, they just want their expenses covered and all the rest. ... Yes, they are semi-affluent, semi-retired ... there is a section of those people that we could tap into to acquire knowledge and skill.' (Radnorshire)

A similar challenge exists to ensure that a greater share of migrant (and indeed all rural residents) income is spent within the rural economy. In the absence of many local rural services the spending potential of migrants (and non-migrants) benefits nearby urban economies. In particular, the absence of a local petrol station seems to result in considerable leakage out of the rural economy. And in contrast to those who allege that the over 50s are set to become an important affluent group (Baker and Speakman, 2006) modal household income data from this study suggests that migrants of this age to remote rural areas are no more or less well-off than the resident non-migrant population: one in every two migrant and non-migrant households headed by an individual aged over 50 possessed an annual pre-tax household income of not more than $£ 20,000$ (with 17 percent and 24 percent respectively having an income of less than $£ 10,000$ per annum). Stereotypical views (Lowe and Speakman, 2006) of affluent migrants moving to remote rural areas may simply disguise hidden levels of household poverty as this cohort ages.

In contrast to their limited economic contribution, pre-retirement age migrants were found to make an important, and significant, contribution to the social fabric of remote rural areas. 
Many early retirement migrants, with time on their hands, become actively involved in community groups and activities. This important role should not be under-estimated. The voluntary sector is set to take on greater importance in the delivery of services as part of the current UK government's Big Society programme (Cabinet Office, 2010). Remote rural areas attracting pre-retirement age migrants would therefore seem particularly well placed to deliver this agenda. A particular challenge will be to not over-rely on this group of volunteers, so that as it ages community activities and indeed the delivery of older person services by the voluntary sector become dependent on older persons themselves.

The need for, and delivery of, specific services for older people in remote rural areas is likely to also become a major challenge in the future. The majority (74 percent) of pre-retirement age migrants to our rural study areas did not possess family or relatives in the destination area. This was particularly pronounced among those moving to Radnorshire (77 percent) and the Isle of Bute (87 percent). A move at this stage of life involved leaving adult children, and therefore potential family support systems, behind in the former place of residence. While the absence of nearby family support may not be significant at present, might it become problematic as migrants advance from the generally healthy mid-life/ retirement stage to later-life? What will happen if they are widowed or develop debilitating health problems? Traditionally, the presence of family is an important source of support for ageing and elderly persons; however, the absence of family support raises important questions about the care of pre-retirement age migrants as they age in place. Such in-migration runs counter to current thinking on the provision of health and social care which seeks to utilise more fully the voluntary sector and family support:

'What's happening within health and social care is that ... we won't have the capacity with an increasing ageing population to meet all the social type demands.... So it's trying to work in partnership with local communities ... and with the voluntaries. .... It's really about the appropriate service at the right time, that's why we are working with the voluntary sector. .... Equally we are expecting individuals to do as much as they can themselves, working closely with families and carers to ask them to take on as much as it is physically possible and we're supporting them in doing that.' (Interview with Northern Health and Social Care Trust (Northern Ireland)).

Only 14 percent of migrant households headed by someone of pre-retirement age at the time of moving had plans to move again in the future. Most resided in Radnorshire and such plans were motivated by a desire to live closer to family or actual retirement. The former motivation acknowledges an absence of family support at their current residence, while the 
latter links migration again with the retirement event. The prospect of ageing in our study areas was explored further with pre-retirement age migrants at interview. Many perceived difficulties. Cecil and Elizabeth Harris are pre-retirement age migrants to Radnorshire. Since the move Elizabeth has been diagnosed with a debilitating illness. Cecil explains:

'[We] didn't appreciate how difficult things were. As Elizabeth got worse - the hospital we use is Hereford, which is forty-five miles away and an hour and a quarters drive each way. When she's in hospital it costs a fortune, actually driving backwards and forwards.'

75-year old Lizzy Shaw moved to Radnorshire with her husband, but since he died in 2007 she explained:

'I've got my house up for sale. ... [I'd move] to be nearer my kids. When I was poorly, it was too far [from England] for them to keep dropping in to see me and I really did feel lonely. I just would have loved someone to knock on the door to say 'how are you?'

Similarly, Eva, a migrant to the Glens of Antrim, fears losing her husband Paul:

'It would be very difficult to live here if you couldn't drive a car,.... And I've often thought if Paul were ever to die before me (please goodness, no) I would find it very difficult to live here on my own. So please God, that doesn't happen! ... I think it would be almost - actually, it would be impossible [to stay here] I would say.'

While Kevin, a pre-retirement age migrant to Radnorshire from England, commented:

'We will have problems growing old here, because there is no transport down into town. ... That's the problem, ..., with outsiders coming in - you don't tend to bring your families or that small cluster of people with you. And once you come out of that group, you are on your own.... We've left our children back in England........ So what happens then that as people get older they rely more on state help which adds to greater costs.'

The difficulties of growing old in Radnorshire especially were starkly reported during an interview with Age Concern Powys:

'Powys is a wonderful place, if you are fit, if you are healthy and if you've got a reasonable income.... It's quite a different story if you are living on the side of a hillside, you've possibly lost your partner, your health is failing ..., you don't have any transport and it's been described as a 'beautiful prison'.'

It is worth also remembering that health care in particular is often limited in rural areas. In Radnorshire, the nearest general and sizeable hospital, for example, is across the English border in Hereford which in itself may give rise to a particular future political issue and challenge: that of an ageing population in an area of devolved Wales being dependent upon hospital care in another (non-devolved) region of the UK.

Some pre-retirement age migrants are therefore asking themselves whether or not they will be able to age in rural place or will need to undertake another, and later life, act of migration. 
The prospect of growing old in rural places is beginning to receive greater academic attention (Milbourne, 2012), while Le Mesurier's (2012) Over the hill? report and accompanying Rural Media Company campaign highlighted the challenges faced by those growing older in the UK countryside. Later life residential adjustment in response to frailty, the onset of debilitating illness, or widowhood has long been acknowledged (Litwak and Longino, 1987; Chevan, 1995). During an era of national population ageing, and associated greater longevity, sizeable (and perhaps new) later life migration flows may emerge. Halfacree and Rivera (2012: 100) acknowledge 'that many, probably most, of pro-rural migrants do settle [in the rural area].' but 'sometimes some element of the rural situation proves to be too existentially problematic' and results in a return to the city or a move to another rural location. We sought to explore subsequent out-migration in this study by asking respondents to the household survey and those interviewed about migrant neighbours and friends to each of our study areas who subsequently left. Few were able to identify such households suggesting, in accordance with Halfacree and Rivera (2012), that most stay or alternatively a reluctance to divulge the required details (if known) to enable us to trace such out-migrants for interview. In any case, information was received for too few to permit meaningful analysis. In the absence of such data, the residential mobility associated with older age groups captured by our household survey and discussions with pre-retirement age migrants at interview about their anticipated future residential moves points to at least two primary residential adjustments in later life by migrants to our remote rural study areas. First, moves may take place to be nearer to adult children as Claire (Kevin's wife) pointed out '[I] wouldn't mind living near them [her children] but I wouldn't want to live with them.' Such sentiments resonate with Lin and Rogerson’s (1995) 'intimacy at a distance’ concept. Likewise, Brian, a pre-retirement age migrant to the Isle of Bute, said of his widowed neighbour: '... because she's had a stroke she’s gone back to live nearer family, she really wasn't coping without a lot of help.' Iris, a pre-retirement age migrant to the Glens of Antrim (from England), foresees the emergence of a related but different mobility flow -a form of chain migration- involving adult children (perhaps at mid-life or retirement) relocating to be closer to elderly parents:

'Long term, I think our kids would like to come over here [from England]. Perhaps not my son: but my daughter for definite. If she, economically, with jobs, with her husband's career and all the rest of it - if they could move over here, they would.' 
Second, later life mobility could be associated with destinations possessing the level of services and facilities required by older age groups. Rather than returning to the city or other large settlement, however, such migrants (and indeed long-term residents at a similar life course stage) adjust their location relative to their 'rural' home by moving up the settlement hierarchy while remaining within an essentially rural environment. This was identified in relation to the Bute study area where local 'within-island' moves dominated among the 65 and over age cohort. All of these moves involved a relocation from a rural environment to one of the island's small settlements; namely Port Bannatyne, Craigmore/ Montford (on the outskirts of the main settlement of Rothesay), and Ardbeg. Undoubtedly, the scale of such relocation at later life would have been even greater if the main town of Rothesay had been included in our survey. For example, 78 year old Katherine Baker living in a remote part of Bute explained:

'[If I can't drive] it would be hopeless living out here. .... I don't know how long that's going to be because I'm pretty old now. ... No. I don't want to leave the island. I think I would probably stay in Rothesay. ... And also to be in the centre of Rothesay so I wouldn't need to go anywhere by bus or anything.'

We suggest, therefore, that Champion's (2005) notion of a 'counterurbanisation cascade' is, for at least some migrants, accompanied by a 'counterurbanisation reverse cascade within the rural environment' in later life. Rather than reject the rural environment completely the residential adjustment deemed necessary as one ages favours a move to a rural settlement capable of meeting the needs of elderly persons.

A greater diversity of migration flows - in-migration, within rural, between rural, and outmigration alongside multiple variations of each - may therefore characterise rural areas in the future. Such multiplicity of flows could represent a particular challenge for service providers and policy-makers.

\section{Conclusion}

We have combined population ageing, recent calls for mid-life to be taken as a new life course stage in migration research, and the retirement transition concept to provide new insights into rural in-migration trends and their associated opportunities and challenges for remote rural areas. We have focused specifically on the pre-retirement age (50-64) group, corresponding as it does to a mid-life and/ or retirement transition life course stage. During a 
period of national population ageing it is argued that this cohort may dominate rural inmigration flows, and will bring with it opportunities and challenges for destination areas. As such, this paper contributes a new empirically grounded dimension to current understandings and debates in life course migration, rural community studies, and population ageing.

In this study, rural in-migration included sizeable flows of households headed by pre- and post-retirement age persons, with a strong counterurban flow in evidence. Nevertheless, there is also evidence of sizeable inter-rural mobility (especially among migrants to Radnorshire) which is rarely identified in rural in-migration research (Gkartzios and Scott, 2010). This finding challenges the idea that pro-rural migration underpinned by sociocultural constructions of rurality is the dominant explanation for rural in-migration (Halfacree and Rivera, 2012). In addition, our findings challenge Halfacree and Rivera’s (2012: 99) assumption that migration 'is often underpinned by over-romanticised, partial or even blatantly inaccurate representations of rural places and rural lives.’ A significant proportion of migrants to Bute and the Glens of Antrim had a priori experience of these places: thus their representation of these rural areas was grounded in experience. This was less so among migrants to Radnorshire, and may help to explain that (relatively) more households were planning a future move away from this area. A sizeable inflow from England was observed in Radnorshire and the Isle of Bute. However, in contrast to the literature which identifies a distinct retirement transition life course stage, in economic status terms our data points to the importance of early retirement facilitating a move into remote rural areas. A future trend away from (or indeed further towards) early retirement is likely to have consequences for rural in-migration flows. It is only in relation to migrant motivations that evidence of a retirement transition life course stage is noted and then it is closely associated with existing business owners. Overall, pre-retirement age migrants were motivated to move for actual or impending retirement and/ or quality of life considerations. Those moving were emptynesters, but in contrast to the literature which has associated rural in-migration with affluent households, we find (in terms of annual income at least) that this is not the case. Instead, some modest income households have released equity from their former homes during the property boom period of the late 1990s and early 2000s to fund a desire for a rural residence and lifestyle. Irrespective of their annual income, such households may of course now have 
considerable savings and/or disposal income as a result of their previous property sale and the absence of a mortgage.

The early retirement status of pre-retirement age heads of households has contributed to a smaller number moving into 'bridging' jobs (and accordingly, self-employment) than might have been expected from the retirement transition literature. Consequently, there is some but limited business set-ups and job creation (when compared with other groups). There is strong evidence that where the move has led to self-employment this is to facilitate a preferred life style as opposed to any entrepreneurial ambition. In contrast to the limited economic consequences, the early retirement status of pre-retirement age migrants has contributed more positively to the social and community opportunities arising from the in-migration of this cohort. Such migrants, and especially those motivated to move for actual or impending retirement reasons, recorded a high incidence of participation, volunteering and holding positions of responsibility in numerous local community groups and activities. Undoubtedly while early retirees will have time to devote to their community in this study we have found that this is accompanied by a strong desire to do so.

Notwithstanding such potential benefits for the rural destination area we have also identified a number of important challenges likely to face these communities in the future. Of particular concern may be the difficulties likely to arise as this cohort of currently healthy and active migrants age in a remote rural environment. Particular difficulties are already apparent and in response new and/ or increasingly sizeable existing later life residential adjustments may emerge. Service providers and policy-makers, informed by an understanding of mid-life migration trends and decision-making, need to plan for the geographical consequences of population ageing. Such planning should seek to maximise the considerable potential offered by pre-retirement age migrants to remote rural areas as well as meet the challenges associated with this cohort as it ages. Rather than wait to respond in an incremental manner to challenges as they emerge, a more proactive approach would seem to be necessary.

Overall, this paper has highlighted the value of incorporating a life course perspective to migration research. By doing so it has enabled us to examine pre-retirement age migration specifically and current and later life opportunities and challenges as this cohort ages. With 
population ageing set to dominate demographic trends for the foreseeable future, the decision-making influences and consequences associated with this particular cohort of inmigrants are likely to have a profound impact on the current and future issues facing remote rural destination areas.

\section{Acknowledgements}

The authors are grateful to the (UK) Economic and Social Research Council for funding this project (Grant Number: RES-062-23-1358) and to Lorna Philip (Aberdeen University) as its co-investigator. We are indebted to the residents and agency representatives in each of our study areas for their participation. Special thanks are also due to Anne Findlay who generated a steady flow of Census tables and maps to assist in our selection of study areas and to Jonathan Bell for his help with fieldwork. Finally, we are grateful to the reviewers for their helpful comments and suggestions.

\section{References}

Akgun, A; Baycan-Levent, T; Nijkamp, P and Poot, J (2011) Roles of local and newcomer entrepreneurs in rural development: A comparative meta-analytic study. Regional Studies 45(9), 1207-1223.

Allen, T (2004) Impacts of population ageing on rural economies. Paper presentation at Ageing and the Countryside Conference (York).

Atterton, J (2006) Ageing and Coastal Communities. Centre for Rural Economy, University of Newcastle upon Tyne.

Baker, R and Speakman, L (2006) the older rural consumer. In P Lowe and L Speakman (Eds) The Ageing Countryside: The growing older population of rural England. Age Concern England: London. Chapter 6, 119-132.

Bailey, A, Blake, M and Cooke, T (2004) Migration, care and the linked lives of dual-earner households. Environment and Planning A 36(9), 1617-1632.

Benson, M and O’Reilly, K (2009) Migration and the search for a better quality of life: a critical exploration of lifestyle migration. Sociological Review 57(4), 608-625.

Bernard, M and Phillips, J (2000) The challenge of ageing in tomorrow's Britain. Ageing and Society 20(1), 33-54.

Bosworth, G (2008) Entrepreneurial in-migrants and economic development in rural England. International Journal of Entrepreneurship and Small Business 6(3), 355-369. 
Bosworth, G (2010) Commercial counterurbanisation: an emerging force in rural economic development. Environment and Planning A 42(4), 966-981.

Bosworth, G and Willett, J (2011) Embeddedness or Escapism? Rural perceptions and economic development in Cornwall and Northumberland. Sociologia Ruralis 51(2), 195-214.

Brown, D and Glasgow, N (2008) Rural Retirement Migration. Springer: New York.

Bures, R (1997) Migration and the Life Course: is there a Retirement Transition? International Journal of Population Geography 3(2), 109-120.

Bures, R (2009) Moving the nest: The impact of coresidential children on mobility in later midlife. Journal of Family Issues 30(6), 837-851.

Cabinet Office (2010) Building the Big Society. UK Cabinet Office: London.

Carter, T, Cook, K and Weinberg C (1997) Planning and expectations of the retirement experience. Educational Gerontology 23(3), 273-88.

Champion, A.G. (2005) The counterurbanisation cascade in England and Wales since 1991: the evidence of a new migration dataset. Revue Belge de Geographie 1-2: 85-101.

Champion, A and Shepherd, J (2006) Demographic Change in Rural England. In P Lowe and L Speakman (Eds) The Ageing Countryside: The growing older population of rural England. Age Concern England: London. Chapter 2, 29-50.

Chevan, A (1995) Holding on and letting go: Residential mobility during widowhood. Research on Aging 17(3), 278-302.

Clark, W and Davies, S (1990) Elderly mobility and mobility outcomes: households in the later stages of life courses. Research on Aging 12(4), 430-462.

Cracknell, R (2010) The Ageing Population. Key Issues for the New Parliament 2010. House of Commons Library Research: London.

Davies, A and James, A (2011) Geographies of Ageing. Social Processes and the Spatial Unevenness of Population Ageing. Ashgate Publishing Limited: Farnham.

Davis, P (2011) Exploring the long-term impact of development interventions within life history narratives in rural Bangladesh. Journal of Development Effectiveness 3(2), 263-280.

Davis, P and Baulch, B (2011) Parallel Realities: Exploring poverty dynamics using mixed methods in rural Bangladesh. Journal of Development Studies 47(1), 118-142.

Davis Smith, J and Gay, P (2005) Active Ageing in Active Communities: Volunteering and the transition to retirement. Policy Press: Bristol.

Divoudi, S and Wishardt, M (2004) Counterurbanisation and its implications for Ryedale. Yorkshire and Humber Regional Review.

DSS (Department of Social Security) (2000) Retirement Pension Information. Available at http://www.dss.gov.uk/lifeevent/benefits/retirement_pension.htm 
Erlinghagen, M and Hank, K (2006) The participation of older Europeans in volunteer work. Ageing and Society 26(4), 567-584.

Fast, J and de Jong Gierveld, J (2008) Ageing, disability and participation. In Keating, N (Ed) Rural Ageing: A Good Place to Grow Old? Policy Press: Bristol. pp.63-73.

Feijten, P; Hooimerijer, P and Mulder, C (2008) Residential Experience and Residential Environment Choice over the Life-course. Urban Studies 45(1), 141-162.

Findlay, A; Short, D and Stockdale, A (2000) Labour Market Impact of Migration to Rural Areas. Applied Geography 20(4), 333-348.

Findlay, A; Stockdale, A; Findlay, A and Short, D (2001) Mobility as a Driver of Change in Rural Britain: An Analysis of the Links between Migration, Commuting and Travel to Shop Patterns. International Journal of Population Geography 7(1), 1-15.

Fischer, P and Malmberg, G (2001) Settled People Don’t Move: On Life Course and (Im-) Mobility in Sweden. International Journal of Population Geography 7(5), 357-371.

Fortuijn, J D; van der Meer, M; Burholt, V; Ferring, D; Quattrini, S; Hallberg, I R; Weber, G and Wenger, C (2006) The activity patterns of older adults: A cross-sectional study in six European countries. Population, Space and Place 12(5), 353-369.

Geist, C and McManus, P (2008) Geographical mobility over the life course: motivations and implications. Population, Space and Place 14(4), 283-303.

Gkartzios, M and Scott, M (2010) Residential mobilities and house building in rural Ireland: Evidence from three case studies. Sociologia Ruralis 50(1), 64-84.

Green, A (2006) Employment and the older person in the countryside. In P Lowe and L Speakman (Eds) The Ageing Countryside: The growing older population of rural England, chapter 5, p.94-118. Age Concern England: London.

Groves-Phillips, S (2013) In-migration and economic activity in rural areas of Wales. (unpublished PhD Thesis, University of the West of England, Bristol).

Halfacree, K (2008) To revitalise counterurbanisation research? Recognising an international and fuller picture. Population, Space and Place 14(6), 479-495.

Halfacree, K (2012) Heterolocal Identities? Counter-Urbanisation, Second Homes, and Rural Consumption in the Era of Mobilities. Population, Space and Place 18(2), 209-224.

Halfacree, K and Rivera, M J (2012) Moving to the Countryside ... and Staying: Lives beyond Representations. Sociologia Ruralis 52(1), 92-114.

Han, SK and Moen, P (1999) Clocking out: Temporal patterning of retirement. American Journal of Sociology 105(1), p.191-236.

Hayward, M, Crimmins E and Wray L (1994) The relationship between retirement life-cycle changes and older men's labor force participation rates, Journal of Gerontology:Social Sciences 49(5), 219-30. 
Herslund, L (2012) The Rural Creative Class: Counterurbanisation and entrepreneurship in the Danish countryside. Sociologia Ruralis 52(2), 235-255.

Jauhiainen, J (2009) Will the retiring baby boomers return to rural periphery? Journal of Rural Studies 25(1), 25-34.

Joseph, A and Skinner, M (2012) Voluntarism as a mediator of the experience of growing old in evolving rural spaces and changing rural places. Journal of Rural Studies 28(4), 380-388.

Kley, S and Mulder, C (2010) Considering, planning, and realizing migration in early adulthood. The influence of life-course events and perceived opportunities on leaving the city in Germany. Journal of Housing and the Built Environment 25(1), 73-94.

Le Mesurier, N (2006) The contributions of older people to rural community and citizenship. In P Lowe and L Speakman (Eds) The Ageing Countryside: The growing older population of rural England, chapter 7, p.133-146. Age Concern England: London.

Le Mesurier, N (2012) Growing older in the English countryside. The Rural Media Company: Hereford.

Lehr, U, Juchtern J Schmitt, M, Sperling, U, Fischer, A Grunedahl, M and Minnemann, E (1998) Anticipation of and adjustment to retirement. Aging Clinical and Experimental Research 10(5), 358-67.

Lin, G and Rogerson, P (1995) Elderly parents and the geographical availability of their adult children. Research on Aging 17(3), 303-331.

Litwak, E and Longino, C F (1987) Migration patterns among the elderly: A developmental perspective. The Gerontologist 27(3), 266-272.

Loretto, W and White, P (2006) Population Ageing and Older Workers: Employers' perceptions, attitudes and policies. Population, Space and Place 12(5), 341-352.

Lowe, P and Baker, R (2006) The Ageing Countryside. Paper presentation at the Ageing society as a driver of rural development conference (York).

Lowe, P and Speakman, L (2006) 'The Greying Countryside' in P Lowe and L Speakman (editors) The Ageing Countryside: The Growing Older Population of Rural England. Age Concern England: London.Chapter 1, pp 9 - 28.

Marshall, V, Clarke, P and Ballantyne P (2001) Instability in the retirement transition: Effects on health and well being in a Canadian study Research on Aging, 23(4), 379-409.

Michielin, F and Mulder, C (2008) Family events and the residential mobility of couples. Environment and Planning A 40(11), 2770-2790.

Milbourne, P (2012) Editorial - Growing old in rural places. Journal of Rural Studies 28(4), 315-317.

Millington, J (2000) Migration and Age: The Effect of Age on Sensitivity to Migration Stimuli. Regional Studies 34(6), 521-33. 
Moen, P; Fields, V; Quick, H and Hofmeister, H (2000) A life-course approach to retirement and social integration. In K Pillemer, P Moen, E Wethington and N Glasgow (Eds) Social Integration in the Second Half of Life. Johns Hopkins: Baltimore.

Murakami, K; Gilroy, R and Atterton, J (2009) Planning for the Ageing Countryside in Japan: The Potential Impact of Multi-habitation. Planning, Practice and Research 24(3), 285-299.

Murdoch, J; Lowe, P; Ward, N and Marsden, T (2003) The differentiated countryside. Routledge: London.

Niedomysl, T (2010) Towards a conceptual framework of place attractiveness: A migration perspective. Geografiska Annaler Series 3 Human Geography 92(1), 97-109.

Office for National Statistics (2011) Older People's Day 2011. Statistical Bulletin (published 29 September 2011).

Oughton, E; Wheelock, J and Baines, S (2003) Micro-businesses and social inclusion in rural households: a comparative analysis. Sociologia Ruralis 43(4), 331-348.

Philip, L., Brown, D. L. and Stockdale, A. (2012) Demographic Ageing in Rural Areas: Insights from the UK and US. In M. Shucksmith, D. L. Brown, S. Shortall, J. Vergunst, and M. E. Warner (Eds) Rural Transformations and Rural Policies in the US and UK. Routledge: London, pp 58-78.

Phillips M (1998) Investigations of the British rural middle classes - Part 2: fragmentation, identity, morality and contestation. Journal of Rural Studies 14(4), 427-443.

Phillips, M (2005) Differential productions of rural gentrification: illustrations from North and South Norfolk. Geoforum 36(4), 477-494.

Plane, D and Jurjevich, J (2009) Ties that no longer bind? The Patterns and Repercussions of Age-articulated Migration. The Professional Geographer 61(1), 4-20.

Putman, R (2000) Bowling Alone. Simon and Schuster: New York.

Quinn, J and Kozy, M (1996) The role of bridge jobs in the retirement transition: Gender, Race and Ethnicity. The Gerontologist 36(3), 363-72.

Reeder, R J (1998) Retiree-Attraction Policies for Rural Development. Agriculture Information Bulletin No.741. US Department of Agriculture, Economic Research Service: Washington, DC.

Rees, P (2003) Demographic Ageing: the broad context, regional diversity. Paper presented at The Regions for All Ages Conference, Birmingham.

Rogers, A (1992) Elderly migration and population redistribution: A comparative study. Belhaven Press: London.

Rossi, P (1955) Why families move: A study in the social psychology of urban residential mobility. Free Press: Glencoe. 
Rutherford, T (2011) Population ageing: statistics. House of Commons Library (London) Standard Note SN/SG/3228.

Serow, W (2003) The economic consequences of retiree concentrations: A review of North American studies. The Gerontologist 43(6), 897-903.

Shucksmith, M., Brown, D. L., Shortall, S., Vergunst, J. and Warner, M. E. (2012) Rural Transformations and Rural Policies in the US and UK. Routledge: London.

Shucksmith, M., Talbot, H. and Lee, R. (2011) Meta-narratives as Heuristic Generalisations of Rural Change. In A Copus and L. Hörnström (Eds) The New Rural Europe: Towards Rural Cohesion Policy. Nordregio: Stockholm.

Skelley, D (2004) Retiree-Attraction Policies; Challenges for Local Governance in Rural Regions. Public Administration and Management 9(3), 212-223.

Skinner, M and Joseph, A (2011) Placing voluntarism within evolving spaces of care in ageing rural communities. Geoforum 76(2), 151-162.

Smith, D (2002) Extending the temporal and spatial limits of gentrification: a research agenda for population geographers. International Journal of Population Geography 8(6), 385-394.

Stallman, J; Deller, S and Shields, M (1999) The economic impact of ageing retirees on a small rural region. The Gerontologist 39(5), 599-610.

Stockdale, A; Findlay, A; and Short, D (2000) The repopulation of rural Scotland: opportunity and threat. Journal of Rural Studies 16(2), 243-257.

Stockdale, A (2006a) The role of a retirement transition in the repopulation of rural areas. Population, Space and Place 12(1), 1-13.

Stockdale, A (2006b) Migration: pre-requisite for rural economic regeneration? Journal of Rural Studies 22(3), 354-366.

Stockdale, A (2010) The diverse geographies of rural gentrification in Scotland. Journal of Rural Studies 26(1), 31-40.

Stockdale, A (2011) A Review of Demographic Ageing in the UK: Opportunities for Rural Research. Population, Space and Place 17(3), 204-221.

Stockdale, A; MacLeod, M and Philip, L (2012) Connected Life Courses: Influences on and Experiences of 'Mid Life’ In-Migration to Rural Areas. Population, Space and Place (DOI:10.1002/psp.1709).

Taylor, M (2008) Living working countryside: The Taylor Review of rural economy and affordable housing. Department for Communities and Local Government: London.

Walters, W H (2002) Later-life migration in the United States: A review of recent research. Journal of Planning Literature 17(1), 37-66. 
Warburton, J and McLaughlin, D (2005) 'Lots of little kindnesses': valuing the role of older Australians as informal volunteers in the community. Ageing and Society 25(5), 715-730.

Wenger, C (2001) Myths and realities of ageing in rural Britain. Ageing and Society 21(1), 117-130.

Wulff, M, Champion, A and Lobo, M (2010) Household diversity and migration in mid-life: Understanding residential mobility among 45-64 year olds in Melbourne, Australia.

Population, Space and Place 16(4), 307-321.

Yeandle, S (2005) Older workers and work-life balance. York Publishing Services: York. 